\title{
Brucine induces the apoptosis of U266 multiple myeloma cells by phosphorylation of $\mathrm{c}$-Jun
}

\author{
YANPING MA, ZHIHUA LI, YIHUA WANG and JING FENG \\ Department of Hematology, The Second Hospital of Shanxi Medical University, Taiyuan, Shanxi 030001, P.R. China
}

Received March 3, 2012; Accepted July 7, 2012

DOI: $10.3892 / \mathrm{mmr} .2012 .1194$

\begin{abstract}
The aim of this study was to investigate the mechanism of the apoptotic effect of brucine on human multiple myeloma (MM) cells. U266 cells $\left(5 \times 10^{4}\right)$ were plated in the presence or absence of brucine $(0,0.05,0.1,0.2$ and $0.4 \mathrm{mg} / \mathrm{ml})$ in 96-well culture plates for 24-72 h. The anti-proliferative response to brucine was assessed by MTT assay. Analysis of the cell cycle of U266 cells treated with or without brucine was performed using flow cytometry. The expression change of c-Jun following treatment with brucine or brucine plus the c-Jun N-terminal kinase (JNK)-specific inhibitor SP600125 was detected using RT-PCR. Brucine appeared to have an effect on apoptosis in a dose- and time-dependent manner. Cell cycle analysis using flow cytometry revealed the accumulation of cells at the sub- $\mathrm{G}_{0} / \mathrm{G}_{1}$ phase. The apoptotic rates were $4.137,10.55,12.31,27.67$ and $29.67 \%(0,0.05,0.1,0.2,0.4 \mathrm{mg} /$ $\mathrm{ml}$ brucine, respectively; $\mathrm{P}<0.01)$. The gray scale values were $0.7961 \pm 0.007$ and $0.4683 \pm 0.003$ (mRNA expression of c-Jun of U266 cells with or without SP600125, respectively). Concentrations of $\leq 0.4 \mathrm{mg} / \mathrm{ml}$ brucine induced apoptosis in U266 cells. Thus, brucine-induced apoptosis in U266 cells occurs via the JNK signaling pathway and phosphorylation of c-Jun.
\end{abstract}

\section{Introduction}

Multiple myeloma (MM) is a malignant clone of plasma cells. The synthesis and secretion of monoclonal immunoglobulin uniform structure and/or light chains alone, accompanied by a reduction in normal immunoglobulin levels, is a feature of MM. The activation of osteoclasts, upsetting the balance of osteoclasts and osteoblasts, appearance of extensive osteolytic lesions and/or malignant tumors and osteoporosis are also characteristic of MM (1). Although high-dose chemotherapy with autologous stem cell transplation and other therapies of

Correspondence to: Professor Yanping Ma, Department of Hematology, The Second Hospital of Shanxi Medical University, Taiyuan, Shanxi 030001, P.R. China

E-mail: mayanpingen@126.com

Key words: multiple myeloma, brucine, apoptosis, c-Jun, caspase enhancing response and survival rates have improved, due to the low proportion of tumor cells (typically less than 1.5\%) (2) and multidrug resistance of tumor cells, MM treatment response is poor and the disease remains incurable, ultimately leading to drug resistance and relapse.

Plants of the Strychnos genus have been used to treat typhoid fever and sore throat, as described in the 'Compendium of Materia Medica'. The 'Chinese Medicine chi' reported that plants of the Strychnos genus can treat fever, swelling, ulcers and sores. Deng et al investigated the effect of Strychnos on HepG2 cells and found that the Strychnos alkaloid treatment of liver cancer is due to its direct cytotoxicity (3). Strychnos alkaloids mostly consist of biologically active substances, but also contain pharmacological and toxicological components, of which $80 \%$ are strychnine and brucine (4). A previous study (5) found that brucine induces apoptosis via the death receptor pathway in multiple myeloma. The present study used reverse transcription polymerase chain reaction (RT-PCR) and flow cytometry to analyze the apoptotic signaling pathway.

\section{Materials and methods}

Cell culture and cell proliferation assay. U266 cells were maintained in RPMI-1640 culture medium with $10 \%$ fetal calf serum, $100 \mathrm{mg} / \mathrm{l}$ penicillin and $100 \mathrm{mg} / \mathrm{l}$ streptomycin, in a $37^{\circ} \mathrm{C}$ incubator supplied with $5 \% \mathrm{CO}_{2}$ at room temperature. The anti-proliferative response of brucine was assessed by MTT assay. U266 cells were plated at a final concentration of $5 \times 10^{4}$ cells $/ \mathrm{ml}$ in the presence or absence of brucine $(0,0.05$, $0.1,0.2$ and $0.4 \mathrm{mg} / \mathrm{ml})$ in a $96-w e l l$ plate. Then $20 \mu 1 \mathrm{MTT}$ $(5 \mathrm{mg} / \mathrm{ml})$ were added at 24,48 and $72 \mathrm{~h}$ following treatment. For the MTT assay, the supernatant was discarded and $200 \mu \mathrm{l}$ DMSO was added, and the 96-well plate was agitated on a micro-vibrator for $10 \mathrm{~min}$. The optical density of each well was measured at $\lambda 492 \mathrm{~nm}$ by an enzyme-immunoassay instrument.

Cell cycle analysis. U266 cells $\left(2 \times 10^{6}\right)$ were treated with or without brucine $(0,0.05,0.1,0.2$ and $0.4 \mathrm{mg} / \mathrm{ml})$ for $48 \mathrm{~h}$. The cells were harvested, washed with PBS at 1,000 rpm for $5 \mathrm{~min}$, fixed with $70 \%$ alcohol, washed again with PBS and stained with propidium iodide in the presence of $100 \mu \mathrm{l}$ RNase A for $30 \mathrm{~min}$ prior to analysis by flow cytometry.

RT-PCR. Total RNA was extracted using a TRIzol reagent. cDNA was amplified from $6 \mu$ l of total RNA using 
Table I. mRNA expression of caspase-3 and c-Jun of U266 cells with or without brucine for 12, 24 and $48 \mathrm{~h}$ (mean $\pm \mathrm{SD}$ ).

\begin{tabular}{lcc}
\hline Group & Caspase- $^{\mathrm{a}}$ & c-Jun \\
\hline Control & $0.2597 \pm 0.020$ & $0.1354 \pm 0.0016$ \\
$12 \mathrm{~h}$ & $0.5488 \pm 0.016$ & $0.2603 \pm 0.0032$ \\
$24 \mathrm{~h}$ & $0.6205 \pm 0.006$ & $0.4874 \pm 0.0068$ \\
$48 \mathrm{~h}$ & $0.6533 \pm 0.009$ & $0.5965 \pm 0.0089$ \\
\hline
\end{tabular}

${ }^{\mathrm{a}} \mathrm{P}<0.01$

Table II. mRNA expression of caspase-3 and c-Jun of U266 cells with or without SP600125 (mean \pm SD).

\begin{tabular}{lcc}
\hline Group & Caspase- $^{\mathrm{a}}$ & c-Jun $^{\mathrm{a}}$ \\
\hline Brucine & $0.7683 \pm 0.0050$ & $0.7961 \pm 0.007$ \\
Brucine+SP600125 & $0.5723 \pm 0.0055$ & $0.4683 \pm 0.003$ \\
\hline
\end{tabular}

${ }^{\mathrm{a}} \mathrm{P}<0.05$.

ThermoScript RT-PCR System with $1 \mu$ l oligo(dT)18 $(0.5 \mu \mathrm{g} / \mu \mathrm{l}), 1 \mu \mathrm{l}$ TransScript $^{\mathrm{TM}}$ RT/RI enzyme, $10 \mu \mathrm{l} 2 \mathrm{X}$ TS Reaction mix, $2 \mu 1$ RNase-free water, analyzed on $2 \%$ agarose gel and confirmed by nucleotide sequencing. The primer pairs used for RT-PCR were: caspase-3 (151 bp): 5 ' - T T T T T C A G A G G G G A T C G T T G - 3 ' a n d 5'-CGGCCTCCACTGGTATTTTA-3'; c-Jun: 5'-CCCCAA GATCCTGAAACAGA-3' and 5'-CCGTTGCTGGACT GGATTAT-3';GADPH:5'-TGAACGGGAAGCTCACTGG-3' and 5'-TCCACCACCCTGTTGCTGGA-3'.

Statistical analysis. Data were expressed as the mean \pm SD and analyzed using SPSS software (SPSS Inc., Chicago, IL, USA). The statistical methods involved two independent sample t-test and analysis of variance (ANOVA). $\mathrm{P}<0.05$ was considered to indicate a statistically significant result.

\section{Results}

Growth inhibitory effects of brucine on U266 cells. The effect of brucine on the proliferative response of U266 cells was analyzed by treating cells with different concentrations of brucine $(0,0.05,0.1,0.2$ and $0.4 \mathrm{mg} / \mathrm{ml})$ for 24,48 and $72 \mathrm{~h}$. The growth inhibitory effects of brucine treatment were assessed by MTT assay. The treated cells showed a significant decrease in proliferation in a dose- and time-dependent manner $(\mathrm{P}<0.05$; Fig. 1$)$. The $\mathrm{IC}_{50}$ value of brucine at $48 \mathrm{~h}$ was $0.16 \mathrm{mg} / \mathrm{ml}$.

Cell cycle analysis. The appearance of the sub- $\mathrm{G}_{0} / \mathrm{G}_{1}$ cell is characteristic of apoptosis. The results of brucine treatment showed that the sub- $\mathrm{G}_{0} / \mathrm{G}_{1}$ phase population significantly increased following brucine treatment in a dose-dependent manner. The sub- $\mathrm{G}_{0} / \mathrm{G}_{1}$ phase population increased to 4.137 ,

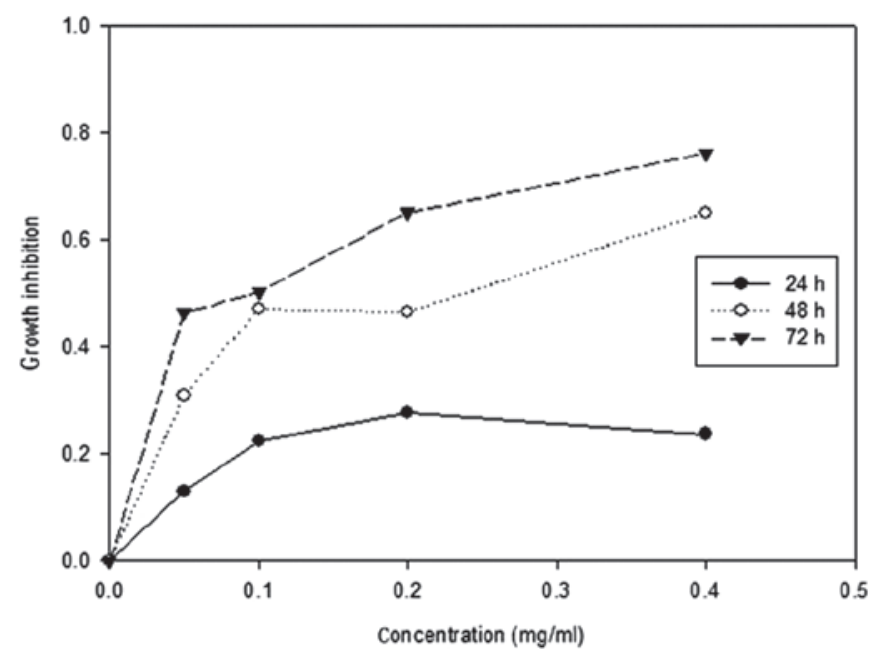

Figure 1. Effect of brucine on U266 cells with different concentrations $(0,0.05,0.1,0.2,0.4 \mathrm{mg} / \mathrm{ml})$ for 24,48 and $72 \mathrm{~h}$. The treated cells showed a significant decrease in proliferation in a dose- and time-dependent manner.

$10.55,12.31,27.67$ and $29.67 \%$ following the exposure of the cells to $0,0.05,0.1,0.2$ and $0.4 \mathrm{mg} / \mathrm{ml}$ brucine concentrations, respectively. This accumulation of cell population at the sub- $\mathrm{G}_{0} / \mathrm{G}_{1}$ phase in a dose-dependent manner indicated an induction of apoptosis.

Caspase-3 is activated in brucine-induced U266 cell apoptosis. Since caspase-3 is an executor of apoptosis, caspase-3 expression was measured in brucine-treated U266 cells by RT-PCR after 12, 24 and 48 h. A brucine-induced timedependent increase of caspase-3 was detected (Fig. 2). The gray value of caspase- 3 was $0.2597 \pm 0.020$ in the control group and increased in the brucine-treated $(0.16 \mathrm{mg} / \mathrm{ml})$ group to $0.5488 \pm 0.016,0.6205 \pm 0.006$ and $0.6533 \pm 0.009$ on exposure of the cells at 12, 24 and $48 \mathrm{~h}$, respectively (Table I).

Effects of brucine on c-Jun expression. c-Jun is a downstream product of the c-Jun N-terminal kinase (JNK)/stress-activated protein kinase (SAPK) signaling pathway. To investigate the effect of c-Jun on the brucine-induced U266 cell apoptosis, the expression of c-Jun was measured in brucine-treated U266 cells by RT-PCR at 12, 24 and $48 \mathrm{~h}$ (Fig. 3). The gray value of c-Jun was $0.1354 \pm 0.0016$ in the control group and increased in the brucine-treated $(0.16 \mathrm{mg} / \mathrm{ml})$ group up to $0.2603 \pm 0.0032$, $0.4874 \pm 0.0068$ and $0.5965 \pm 0.0089$ upon exposure of the cells at 12,24 and $48 \mathrm{~h}$, respectively (Table I).

Caspase-3 and c-Jun expression. To verify that the activation of caspase- 3 and c-Jun is associated to the JNK signaling pathway, the expression of caspase-3 and c-Jun was measured after the specific inhibitor of the JNK signaling pathway, SP600125, was added by RT-PCR (Fig. 4). The gray values of caspase- 3 and c-Jun were $0.7683 \pm 0.0050$ and $0.7961 \pm 0.007$, respectively, in the brucine-treated $(0.16 \mathrm{mg} / \mathrm{ml})$ group. By contrast, a decrease in the brucine $(0.16 \mathrm{mg} / \mathrm{ml})$ and SP600125 group down to $0.5723 \pm 0.0055$ and $0.4683 \pm 0.003$ was detected following treatment for $24 \mathrm{~h}$ (Table II). 

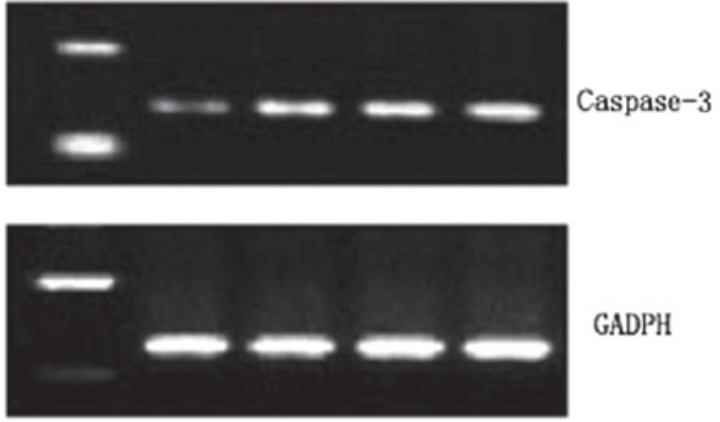

GADPH

Varker control $12 \mathrm{~h} \quad 24 \mathrm{~h} \quad 48 \mathrm{~h}$

Expression of Caspase- 3 with time

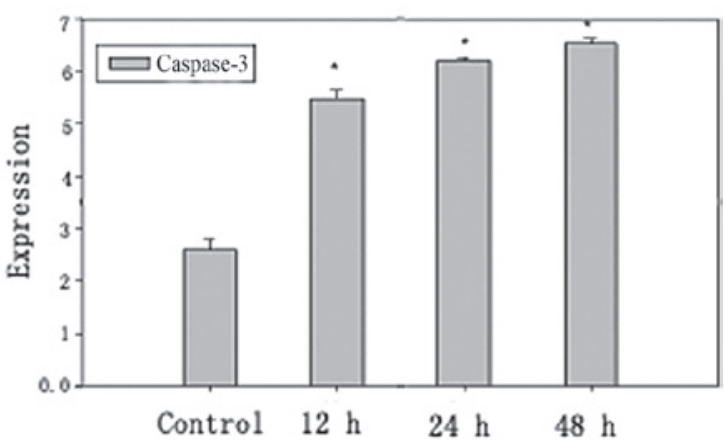

Figure 2. Effects of brucine on caspase-3 expression at various time points. GADPH was used as an internal reference. Each experiment was performed in triplicate.
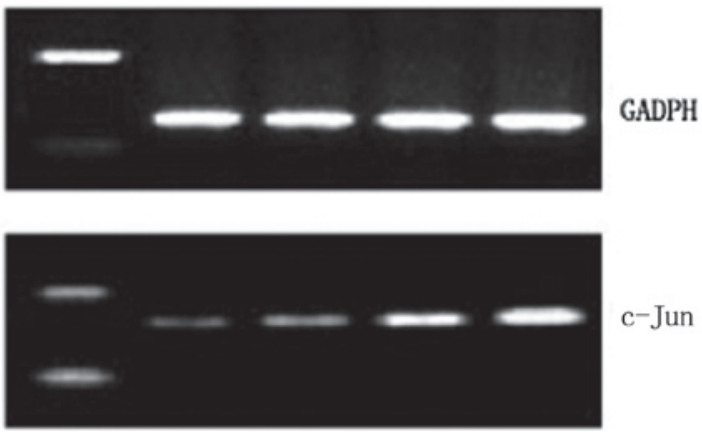

Narker control $\quad 12 \mathrm{~h} \quad 24 \mathrm{~h} \quad 48 \mathrm{~h}$

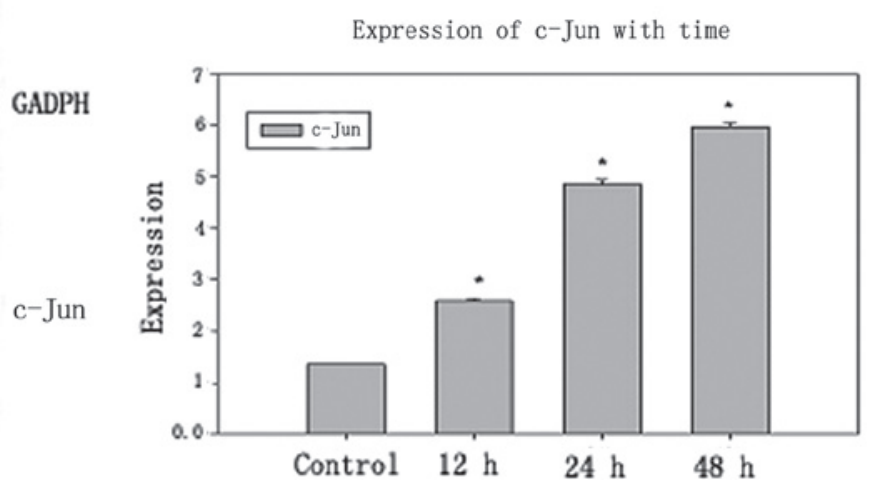

Figure 3. Effects of brucine on c-Jun expression at various time points. GADPH was used as an internal reference. Each experiment was performed in triplicate.

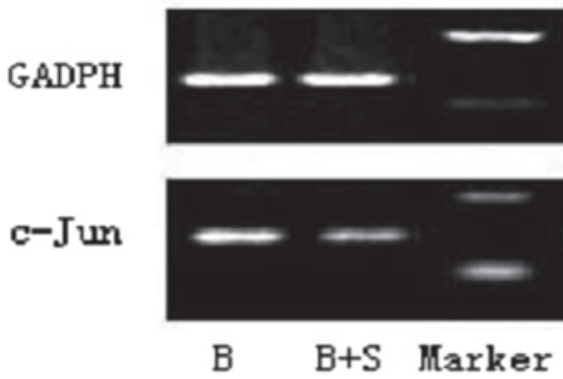

GADPH

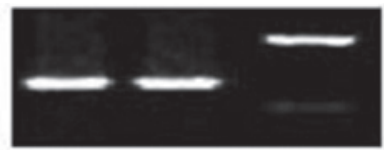

Caspase-3

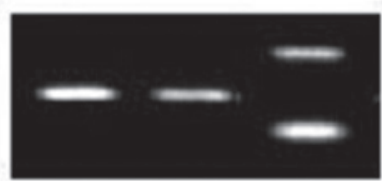

B B+S Marker

Figure 4. Expression of caspase-3 and c-Jun after adding the inhibitor SP600125. GADPH was used as an internal reference. Each experiment was performed in triplicate. B, brucine; B+S, brucine+SP600125.

\section{Discussion}

The process of programmed cell death (PCD), or apoptosis, is required to maintain homeostasis (6). Apoptosis is closely correlated with the occurrence of a variety of diseases (including autoimmune disease and cancer) (7). Apoptosis is distinct from necrosis and is a process in which cells are actively involved in initiating a series of gene activations to adapt to the environment. MM is an incurable plasma cell neoplasm characterized by the accumulation of malignant plasma cells in the bone marrow. The occurrence and development of MM is associated to abnormal proliferation and the inhibition of apoptosis of tumor cells.
This study was performed to evaluate the response to brucine using the human MM line cell, U266. These results confirmed the anti-proliferative effect of brucine on the U266 cell line, with an $\mathrm{IC}_{50}$ value of $0.16 \mathrm{mg} / \mathrm{ml}$ at $48 \mathrm{~h}$ (Fig. 1). Furthermore, the flow cytometric analysis was performed on brucine-treated U266 cells to analyze the type of cell death process (apoptosis or necrosis). The results demonstrated that the sub- $\mathrm{G}_{0} / \mathrm{G}_{1}$ cell population increased in a dose-dependent manner.

Mitogen-actived protein kinase (MAPK) is a significant method of signal transduction in eukaryotes and is key in the regulation of gene expression (8). The classic MAPK signaling pathway is the MAPKKKs $\rightarrow$ MAPKKs $\rightarrow$ MAPKs continuous 
enzymatic reaction $(8,9)$. The MAPK family includes extracellular signal regulated kinase (ERK), JNK/SAPK and p38 categories (10). The dynamic balance of JNK, p38 and ERK determines cell survival and apoptosis (11). JNK is a serine/ threonine protein kinase located in the cytoplasm with a molecular mass of $54 \mathrm{kDa}(12)$. Due to its interaction with the $\mathrm{N}$-terminal activation domain of c-Jun and the phosphorylation of serine 63 and 73, JNK has been designated as c-Jun $\mathrm{N}$-terminal kinase (10). c-Jun belongs to the Jun subfamily (c-Jun, Jun B and Jun D) and forms the center of transcription factor-activated protein-1 (AP-1) as well as dimers of basic leucine zippers. c-Jun and Fos (v-Fos, c-Fos, FosB and FosL1, FosL2) form homo- or heterodimers, which activate transforming growth factor (ATF-2, LRF-1/ATF-3, B2ATF, JDP1 and JDP2) or fibrosarcoma tendon membrane protein (c-Maf, MafB, MafA, MafG/F/K and NRL). Phosphorylation of c-Jun and ATF-2, and activation of the transcription factor (AP-1), combined with Fas through the activation of caspase-8 (13). JNK induces apoptosis via the death receptor pathway. JNK may also act via the phosphorylation of Bcl-2 and Bcl-xL (14). The release of cytochrome $C$, and activation of caspase- 9 induces apoptosis through the mitochondrial pathway (15). In the anti-Fas monoclonal antibody induction apoptosis of MM cells, JNK/SAPK in the cytoplasm and transcription factor c-Jun were induced $(16,17)$. The roselle extract is known to activate JNK/p38MAPK (18). The phosphorylation of the target proteins of c-Jun activates the signal transduction of apoptosis-related proteins, including the Fas-mediated signal, and induces apoptosis (19).

Findings of our previous study (5) have verified that the apoptosis induced by brucine occurs via the death receptor pathway. To investigate the signaling pathways of apoptosis, the U266 cells treated with brucine for 12,24 and $48 \mathrm{~h}$ were collected. c-Jun, the downstream product of JNK and caspase-3, which is the executor of apoptosis, was detected (Figs. 2 and 3). The results showed that the gray value in brucine-treated cells for 12,12 and $48 \mathrm{~h}$ increased up to $0.5488 \pm 0.016,0.6205 \pm 0.006,0.6533 \pm 0.009$ for caspase -3 and $0.2603 \pm 0.0032,0.4874 \pm 0.0068,0.5965 \pm 0.0089$ for c-Jun, respectively (Table I; $\mathrm{P}<0.01$ ), and demonstrated that caspase-3 and c-Jun were activated in brucine-treated cells. In addition, caspase- 3 and c-Jun were detected again following the addition of the specific JNK inhibitor, SP600125 (20). The results demonstrate that the gray value of caspase- 3 and c-Jun were decreased to $0.5723 \pm 0.0055$ and $0.4683 \pm 0.003$, respectively (Fig. 4, Table II), and that the activation of caspase-3 and c-Jun in brucine-treated cells is capable of inhibition by the specific JNK inhibitor SP600125. We suggest that brucine, via phosphorylation of c-Jun by the JNK signaling pathway, induces apoptosis in the human MM cell line U266.

In the present study, we suggest that the anti-proliferative activity of brucine on U266 cells is due to apoptosis. Preliminary analysis of the apoptosis mechanism demonstrated that the JNK signaling pathway was activated in the apoptotic U266 cells treated with brucine. The present study suggests that brucine has possible anti-cancer effects and provides a theoretical basis for the clinical treatment of MM. However, the inhibitory growth effect of brucine on other myeloma cell lines and resistant cell lines as well as other signaling pathways remains to be determined. Additionally, the overall level of apoptosis and toxicity caused by brucine requires additional investigation.

\section{References}

1. Wei ZL and Wang XH: The development of NF- $\kappa B$ in the multiple myeloma. Med Res Nov 36: 98-101, 2007.

2. Spisek R, Charalambous A, Mazumder A, et al: Bortezomib enhances dendritic cell (DC)-mediated induction of immunity to human myeloma via exposure of cell surface heat shock protein 90 on dying tumor cells: therapeutic implications. Blood 109: 4839-4845, 2007.

3. Rao PS, Ramanadham M and Prasad MN: Anti-proliferative and cytotoxic effects of Strychnos nux-vomica root extract on human multiple myeloma cell line - RPMI 8226. Food Chem Toxicol 47: 283-288, 2009.

4. Deng X, Yin F, Lu X, et al: The apoptotic effect of brucine from the seed of Strychnos nux-vomica on human hepatoma cells is mediated via Bcl-2 and $\mathrm{Ca}^{2+}$ involved mitochondrial pathway. Toxicol Sci 91: 59-69, 2006.

5. Li ZH, Ma YP, Wang YH and Feng J: Apoptosis of U266 cells induced by brucine through death-receptor pathway. J Leuk Lymphoma 19: 724-731, 2010.

6. Jiao JX and Gao WJ: The research progress of the mechanism on the cellular signal transmission. Chin J Gerontol 30: 853-856, 2010 (In Chinese).

7. Wen $\mathrm{ZH}$ and Wang XH: Apoptosis and multiple myeloma. North China Coal Med Coll 8: 778-781, 2006.

8. Liang XM and Yang KD: Caspase, JNK/SAPK, P38 MAPK and apoptosis. Foreign Med Sci (section hygiene) 35: 5-10, 2008.

9. Wan KF, Chan SL, Sukumaran SK, et al: Chelerythrine induces apoptosis through a Bax/Bak-independent mitochondrial mechanism. J Biol Chem 283: 8423-8433, 2008.

10. Du L, Wang FY, Zhang L, et al: Advance in the research of JNK dependent apoptosis. China Trop Med 18: 841-844, 2008 (In Chinese).

11. Xiao Y, Yang FQ, Li SP, et al: Furanodiene induces G2/M cell cycle arrest and apoptosis through MAPK signaling and mitochondria-caspase pathway in human hepatocellular carcinoma cells. Cancer Biol Ther 6: 1044-1050, 2007.

12. Hu Z, Tao YG, Yang LF, et al: Effect of JIP on the proliferation and apoptosis of nasopharyngeal carcinoma cells through interaction with JNK mediated pathway. Prog Biochem Biophys 30: 579-585, 2003.

13. Papa S, Zazzeroni F, Pham CG, et al: Linking JNK signaling to NF-kappaB: a key to survival. J Cell Sci 117: 5197-5208, 2004.

14. Murakami Y, Aizu-Yokota E, Sonoda Y, et al: Suppression of endoplasmic reticulum stress induced caspase activation and cell death by the over expression of Bcl-xl or Bcl-2. J Biochem 141: 401-410, 2007.

15. Peng J, Mao XO, Stevenson FF, et al: The herbicide paraquat induces dopaminergic nigral apoptosis through sustained activation of the JNK pathway. J Biol Chem 279: 32626-32632, 2004.

16. Largo C, Alvarez S, Saez B, et al: Identification of overexpressed genes in frequently gained/amplified chromosome regions in multiple myeloma. Hematologica 91: 184-191, 2004.

17. Lin HH, Chen JH, KuoWH, et al: Chemopreventive properties of Hibiscus sabdariffa L. on human gastric carcinoma cells through apoptosis induction and JNK/p38 MAPK signaling activation. Chem Biol Interac 165: 59-75, 2007.

18. Gong X, Wang M, Tashiro S, et al: Involvement of JNK-initiated p53 acccumulation and phosphorylation of p53 in pseudolaric acid B induced cell death. Exp Mol Med 38: 428-434, 2006.

19. Junttila MR, Li SP and Westermarck J: Phosphatase-mediated crosstalk between MAPK signaling pathways in the regulation of cell survival. FASEB J 22: 954-965, 2008.

20. Matsumoto N, Imamura R and Suda T: Caspase- 8 and JNK dependent AP-1 activation is required for Fas ligand-induced IL-8 production. FEBS J 274: 2376 -2384, 2007. 